\title{
Comparative tolerance of Pinus radiata and microbial activity to copper and zinc in a soil treated with metal-amended biosolids
}

\author{
Paramsothy Jeyakumar • Paripurnanda Loganathan • \\ Christopher W. N. Anderson • Sivalingam Sivakumaran • \\ Ronald G. McLaren
}

Received: 17 March 2013 / Accepted: 22 October 2013 / Published online: 12 November 2013

(C) Springer-Verlag Berlin Heidelberg 2013

\begin{abstract}
A study was conducted to evaluate the effects of elevated concentrations of copper $(\mathrm{Cu})$ and zinc $(\mathrm{Zn})$ in a soil treated with biosolids previously spiked with these metals on Pinus radiata during a 312-day glasshouse pot trial. The total soil metal concentrations in the treatments were $16,48,146$ and $232 \mathrm{mg} \mathrm{Cu} / \mathrm{kg}$ or 36, 141, 430 and $668 \mathrm{mg} \mathrm{Zn/kg}$. Increased total soil $\mathrm{Cu}$ concentration increased the soil solution $\mathrm{Cu}$ concentration $(0.03-0.54 \mathrm{mg} / \mathrm{L})$ but had no effect on leaf and root dry matter production. Increased total soil $\mathrm{Zn}$ concentration also increased the soil solution $\mathrm{Zn}$ concentration $(0.9-362 \mathrm{mg} / \mathrm{L})$. Decreased leaf and root dry matter were recorded above the total soil $\mathrm{Zn}$ concentration of $141 \mathrm{mg} / \mathrm{kg}$ (soil solution $\mathrm{Zn}$ concentration, $>4.4 \mathrm{mg} / \mathrm{L}$ ). A lower percentage of $\mathrm{Cu}$ in the soil soluble+exchangeable fraction $(5-12 \%)$ and lower $\mathrm{Cu}^{2+}$ concentration in soil solution $(0.001-0.06 \mu \mathrm{M})$ relative to $\mathrm{Zn}$ (soil soluble + exchangeable fraction, 12-66 \%; soil solution $\mathrm{Zn}^{2+}$ concentration, 4.5-4,419 $\mu \mathrm{M}$ ) indicated lower bioavailability of $\mathrm{Cu}$. Soil dehydrogenase activity decreased with every successive level of $\mathrm{Cu}$ and $\mathrm{Zn}$ applied, but the reduction was
\end{abstract}

Responsible editor: Zhihong Xu

P. Jeyakumar $(\triangle) \cdot$ P. Loganathan $\cdot$ C. W. N. Anderson

Soil and Earth Sciences, Institute of Agriculture and Environment,

Massey University, Palmerston North, New Zealand

e-mail: j.jeyakumar@massey.ac.nz

P. Loganathan

Faculty of Engineering, University of Technology, Sydney, City

Campus, Broadway, NSW 2007, Australia

\section{S. Sivakumaran}

Sustainable Production-Soil Water Environment, Plant \& Food

Research, Palmerston North, New Zealand

R. G. McLaren

Soil and Physical Sciences Department, Agriculture and Life

Sciences Faculty, Lincoln University, Lincoln, New Zealand higher for $\mathrm{Zn}$ than for $\mathrm{Cu}$ addition. Dehydrogenase activity was reduced by $40 \%\left(\mathrm{EC}_{40}\right)$ at the total solution-phase and solidphase soluble+exchangeable $\mathrm{Cu}$ concentrations of $0.5 \mathrm{mg} / \mathrm{L}$ and $14.5 \mathrm{mg} / \mathrm{kg}$, respectively. For $\mathrm{Zn}$ the corresponding $\mathrm{EC}_{50}$ were $9 \mathrm{mg} / \mathrm{L}$ and $55 \mathrm{mg} / \mathrm{kg}$, respectively. Based on our findings, we propose that current New Zealand soil guidelines values for $\mathrm{Cu}$ and $\mathrm{Zn}(100 \mathrm{mg} / \mathrm{kg}$ for $\mathrm{Cu} ; 300 \mathrm{mg} / \mathrm{kg}$ for $\mathrm{Zn})$ should be revised downwards based on apparent toxicity to soil biological activity $(\mathrm{Cu}$ and $\mathrm{Zn})$ and radiata pine ( $\mathrm{Zn}$ only) at the threshold concentration.

Keywords Bioavailability · Bio accumulation factor .

Dehydrogenase activity $\cdot \mathrm{EC}_{50} \cdot$ Metal toxicity $\cdot$ Radiata pine $\cdot$ Rhizosphere $\cdot$ Soil metal fractions

\section{Introduction}

Pinus radiata (radiata pine) is one of the world's most commercially important conifers, and its planting covers a total global area now exceeding 4.3 million hectares. It is grown extensively as an exotic timber species in several countries, such as New Zealand, Australia, Chile, South Africa and Spain (Sutton 1999; Toro and Gessel 1999; Putoczki et al. 2007; Sevillano-Marco et al. 2009). Radiata pine forestry has a very important place in the economy of New Zealand and constitutes $89.5 \%$ of the national plantation forestry land area (approximately 1.6 million ha) (NZFOA 2009).

Soil cultivated for pine forestry production is often low in essential nutrients and deficiencies can limit plant growth (Mosquera-Losada et al. 2010). One strategy to improve the fertility of pine forestry soils is to apply biosolids at rates of up to 6.7 tha/year (NZWWA 2003). Biosolids application to pine forestry soils is often considered to be a relatively safe option for disposal of this waste. This is because the biosolids can improve 
and maintain productivity of soils by means of increasing organic matter content, aggregate stability, porosity, water infiltration rate and simulate plant growth (Wang et al. 2006). Further, there is little risk of contaminants from the biosolids entering the human food chain under this type of land use. However, due to repeated surface applications of biosolids, it has been reported that heavy metal bioavailability may be increased in the litter-rich surface soil, potentially leading to some degree of movement of these heavy metals into the underlying mineral soil, and eventually into groundwater (McLaren et al. 2007; Su et al. 2008). If these lands are converted to crop production in the future, then heavy metals accumulated in the forest soil may represent an unacceptable risk to the food chain (McLaren et al. 2010).

Many studies have attempted to investigate the toxicity effect of $\mathrm{Cu}$ and $\mathrm{Zn}$ on pines grown in metal-contaminated soils or in solution culture (Hartley et al. 1999; Gratton et al. 2000; Egiarte et al. 2009). Metal accumulation and movement in pine forest soils that have been amended with biosolids and in the litter layer beneath pine trees have been studied in recent trials (McLaren et al. 2007; Su et al. 2008; Egiarte et al. 2009; Mosquera-Losada et al. 2009). However, in each of these studies, no toxic effect of $\mathrm{Cu}$ and $\mathrm{Zn}$ on pine growing in biosolids-amended soil could be quantified. We believe this is because the metal levels tested were not sufficiently high, and not representative of long-term biosolids amendment strategies to forestry soil. For example, Fuentes et al. (2007a) showed that soils amended with low levels of $\mathrm{Cu}$ and $\mathrm{Zn}$ contaminated biosolids (44 and $122 \mathrm{mg} / \mathrm{kg}$ soil, respectively) had no adverse effect on pine growth. Similarly, Ferreiro-Dominguez et al. (2012) showed that forest soils in Northwest Spain fertilised with biosolids did not induce a phytotoxic effect on pines when the total soil $\mathrm{Cu}$ concentration ranged from 1.9 to $5.2 \mathrm{mg} / \mathrm{kg}$. Under the same field conditions, Rigueiro-Rodríguez et al. (2012) demonstrated that total soil $\mathrm{Zn}$ at a rate of $35-45 \mathrm{mg} / \mathrm{kg}$ had no adverse effect on pines. Because these studies did not show $\mathrm{Cu}$ and $\mathrm{Zn}$ toxicity to pines, it was not possible to determine the critical levels for $\mathrm{Cu}$ and $\mathrm{Zn}$ toxicity. In order to determine the threshold levels of $\mathrm{Cu}$ and $\mathrm{Zn}$ toxicity to pine, higher concentrations of $\mathrm{Cu}$ and $\mathrm{Zn}$ spiked biosolids should be used.

Soil microorganisms are also affected by the presence of high concentrations of metals in soil (Giller et al. 1998), but the threshold of phytotoxicity may not be at the same metal concentration level as for plants. However, the comparative effect of $\mathrm{Cu}$ and $\mathrm{Zn}$ toxicity on microorganisms and pine is lacking in scientific literature. Alloway (1995) stated that the microorganisms are more vulnerable to $\mathrm{Cu}$ and $\mathrm{Zn}$ toxicity than higher plants because they have less well developed homeostatic defence mechanisms. Therefore, in order for regulatory agencies to set guidelines for the safe disposal of metal-contaminated biosolids to pine forest land, threshold heavy metal toxicity levels both to plants and soil microorganisms need to be assessed. Jeyakumar et al. (2010) studied the effect of incorporating $\mathrm{Cu}(12-226 \mathrm{mg} / \mathrm{kg}$ soil) and Zn (25-686 mg/kg soil) spiked biosolids into soils on poplar plant growth and soil microbial activity in a pot trial conducted for 147 days. They found that $\mathrm{Cu}$ was not phytotoxic to poplar, whereas $\mathrm{Zn}$ caused phytotoxicity at a total soil $\mathrm{Zn}$ concentration beyond $141 \mathrm{mg} / \mathrm{kg}$. All rates of $\mathrm{Cu}$ and $\mathrm{Zn}$ addition decreased soil microbial activity, and $\mathrm{Cu}$ was identified as a more toxic metal than $\mathrm{Zn}$ to soil microorganisms.

This paper presents the results of a study that was conducted to determine the bioavailability of $\mathrm{Cu}$ and $\mathrm{Zn}$ in soils amended with biosolids, and the effect of $\mathrm{Cu}$ and $\mathrm{Zn}$ on growth and metal uptake by radiata pine, and on soil microbial activity using elevated concentrations of the metals. A key objective of this work was to quantify critical levels of $\mathrm{Cu}$ and $\mathrm{Zn}$ in soil that can be considered toxic to radiata pine and soil microbial activity so that more reliable environmental threshold guidelines can be defined.

\section{Materials and methods}

\section{Treatments and design}

One-year-old radiata pine (P. radiata D. Don) clones (96004) collected from ArborGen plant nursery, New Zealand were used in a controlled plant growth unit experiment. Radiata pine was planted in pots containing $13 \mathrm{~kg}$ of biosolidamended recent soil ("Dystric Fluventic Eutrudept") classified as "Manawatu fine sandy loam" (Hewitt 1998). Soil was amended with biosolids in three separate levels of $\mathrm{Cu}$ or $\mathrm{Zn}$ which were previously spiked with metal sulphate salts $\left(\mathrm{CuSO}_{4} .5 \mathrm{H}_{2} \mathrm{O}\right.$ and $\left.\mathrm{ZnSO}_{4} .7 \mathrm{H}_{2} \mathrm{O}\right)$, as explained by Jeyakumar et al. (2008). The control treatment utilised biosolids not amended with metals. There were six metal-spiked treatments with the following total metal concentrations (in milligrams per kilogram soil): $\mathrm{Cu} 48$ (designated Cu1), 146 (Cu2), 232 (Cu3), and Zn 141 (Zn1), 430 (Zn2), 668 (Zn3). The $\mathrm{Cu}$ and $\mathrm{Zn}$ concentration of the control treatment (designated both $\mathrm{Cu} 0$ and $\mathrm{Zn} 0$ ) was 16 and $36 \mathrm{mg} / \mathrm{kg}$, respectively. These seven treatments were replicated three times in a randomised complete block design (RCBD). Soil moisture content of the pots was maintained at $80 \%$ "pot field capacity" and the temperature of the plant growth unit was regulated at a minimum of 9 $\pm 5{ }^{\circ} \mathrm{C}$ (night) and a maximum of $18 \pm 6{ }^{\circ} \mathrm{C}$ (day). The experiment was concluded over 312 days. At harvest, plant shoots, roots, and rhizosphere and bulk soil samples from each pot were collected. The following soil parameters were measured: total soil $\mathrm{Cu}$ and $\mathrm{Zn}$ concentration; $\mathrm{Cu}$ and $\mathrm{Zn}$ fractionation using a sequential extraction procedure; total soil solution $\mathrm{Cu}$ and $\mathrm{Zn}$ concentration and metal speciation; the cations $\mathrm{Ca}^{2+}$, $\mathrm{Mg}^{2+}, \mathrm{K}^{+}, \mathrm{Na}^{+}$, and $\mathrm{NH}_{4}{ }^{+}$; the anions $\mathrm{SO}_{4}{ }^{2-}, \mathrm{Cl}^{-}$, and $\mathrm{NO}_{3}{ }^{-}$; dissolved organic carbon; $\mathrm{pH}$; and dehydrogenase activity in rhizosphere and bulk soils. Radiata pine needle and root dry matter (DM) yields, and root and needle $\mathrm{Cu}$ and $\mathrm{Zn}$ concentration were also measured. 
Plant harvest and soil sampling

Plant aerial biomass was collected from each pot 312 days after the initiation of the experiment. The bulk soil was separated from rhizosphere soil and root, and care was taken not to loosen rhizosphere soils from the root ball of the plant. The rhizosphere soil attached to the roots was separated by vigorously shaking the roots inside a bag (Liu et al. 2008). Bulk and rhizosphere soil were split into three equal size sub-samples. One sub-sample was used for soil $\mathrm{pH}$ measurement and soil solution extraction. The second sub-sample was transferred into a sterilised container at $28^{\circ} \mathrm{C}$ for measurement of dehydrogenase activity. The third subsample was air dried and sieved through a 1-mm stainless steel sieve for total metal analysis and fractionation. Root and needles were separately dried (at $60^{\circ} \mathrm{C}$ ) and ground using a Cyclotech 1093 Plant Mill equipped with a stainless steel blade. The dry weight of the harvested material was recorded and the ground plant material was stored for chemical analysis.

\section{Chemical analysis}

Soil $\mathrm{pH}$ was measured (soil/water 1:2.5 $w / w$ ) using a Eutech Instruments Cyber Scan pH 310 meter. Soil solution was extracted from each subsample by centrifuging the moist soil at $11953 \mathrm{G}$ and $48{ }^{\circ} \mathrm{C}$ for $30 \mathrm{~min}$. The resulting solutions were filtered through a $0.45-\mathrm{mm}$ filter and analysed for $\mathrm{pH}, \mathrm{Cu}$ and $\mathrm{Zn}$ concentration, and base cation and anion concentration. The $\mathrm{Cu}$ concentration was determined by graphite furnace atomic absorption spectrometry (Analyst 600, Perkin Elmer); Zn, Mg, Na, $\mathrm{K}$, and $\mathrm{Ca}$ concentrations were determined by flame atomic absorption spectrometry (FAAS: GBC Avanta $\sum$ ). The soil solution $\mathrm{SO}_{4}{ }^{2-}$ and $\mathrm{Cl}^{-}$concentrations were determined by ion chromatography, and $\mathrm{NO}_{3}{ }^{-}$and $\mathrm{NH} 4+$ by an automated analysis technique (Tecator 1983). Dissolved organic carbon was measured using a Shimadzu TOC-5000 analyzer (Wu et al. 1990). The Windermere humic aqueous model (WHAM; Centre for Ecology and Hydrology 2002) was used to define the speciation of $\mathrm{Cu}$ and $\mathrm{Zn}$ in the soil solution. The soil solution cations $\left(\mathrm{Ca}^{2+}\right.$, $\mathrm{Mg}^{2+}, \mathrm{K}^{+}, \mathrm{Na}^{+}$, and $\left.\mathrm{NH}_{4}^{+}\right)$, anions $\left(\mathrm{SO}_{4}{ }^{2-}, \mathrm{Cl}^{-}\right.$, and $\mathrm{NO}_{3}{ }^{-}$), dissolved organic carbon concentration, and $\mathrm{pH}$ were used as the model inputs. The total soil $\mathrm{Cu}$ and $\mathrm{Zn}$ concentration was measured using a wet digestion method developed by Kovács et al. (2000). A sequential extraction technique developed by Tessier et al. (1979) and modified by McLaren and Clucas (2001) was used to determine the solid-phase $\mathrm{Cu}$ and $\mathrm{Zn}$ metal fractionation in the soil. Root and needle samples $(0.4 \mathrm{~g})$ were digested separately using $10 \mathrm{~mL}$ of $65 \% \mathrm{HNO}_{3}$. The bio-concentration factor (BCF), defined as a ratio of metal concentration in plant shoots to metal concentration in soil, was calculated to assess the ability of the plants to uptake $\mathrm{Cu}$ and $\mathrm{Zn}$ from the soil and to translocate these metals to shoots.

Certified reference materials were used to ensure the accuracy of the measurements. For total metal analysis, river sediment sample US NBS-SRM-1645 and a sewage sludge BCR CRM 145R sample from the Commission of the European Community were used. The measured mean $\mathrm{Cu}$ and $\mathrm{Zn}$ concentration for these reference materials were 101-104\% of the expected values. For metal fractionation, internal standards (Hort 1 and 2) were used as standard reference material, and the concentration of metal associated with each fraction was found to be within $92-104 \%$ of the expected mean values. Blanks used in all analysis showed only $<0.2-0.9 \%$ of the sample concentration, and were used to correct the unknown sample values. A Wageningen plant standard (2004-04, no. 2) was used as a standard reference material to verify the accuracy of the analytical procedure from radiata pine biomass. Analytical derived metal concentrations were from 95 to $104 \%$ of the reported value.

\section{Dehydrogenase activity}

The effect of $\mathrm{Cu}$ and $\mathrm{Zn}$ on the biological activity of soil was assessed by determining dehydrogenase activity in the soil (Taylor et al. 2002; Mills et al. 2006). The method of Chander and Brookes (1991) was used to quantify dehydrogenase activity. Briefly, $5 \mathrm{~g}$ of field moist soil was mixed with $3 \mathrm{~mL}$ of $3 \%$ 2,3,5-triphenyl tetrazolium chloride and $0.1 \mathrm{~g} \mathrm{CaCO}_{3}$, and incubated for $24 \mathrm{~h}$ at $28{ }^{\circ} \mathrm{C}$. Triphenyl formazan (TPF) formed in the reaction was extracted with methanol and the concentration was measured by absorbance at $485 \mathrm{~nm}$ using a spectrophotometer (DU-640; Beckman, Krefeld).

\section{Data analysis}

Significant differences among treatments $(n=3)$ for all measured parameters were tested by the "Analysis of variance" (one-way ANOVA) procedure and Duncan multiple range test at the $95 \%$ confidence level $(P=0.05)$ using $\mathrm{SAS}^{\circledR}$ 9.1.2 statistical software (SAS Institute Inc 2004). In addition, a set of simple correlation analyses relating the soil dehydrogenase activity with the metal concentrations in the solid-phase fraction and the soil solution species was performed using SigmaPlot 10 (Systat Software Inc. 2006) curve-fitting software. The dehydrogenase activities in the metal-spiked treatments were calculated as a percentage of activity of the control treatment. The equations used for the curve fitting were described by Jeyakumar et al. (2010).

\section{Results and discussion}

Dry matter yield and metal concentration in the plants

Increased $\mathrm{Cu}$ levels had no significant effect on either needle or root DM yield (Table 1). However, the concentration of $\mathrm{Cu}$ in needles and roots for all $\mathrm{Cu}$ treatments was significantly increased with every level of $\mathrm{Cu}$ applied. The needle $\mathrm{Cu}$ 
concentration at all levels of $\mathrm{Cu}(4.2-7.3 \mathrm{mg} / \mathrm{kg})$ was higher than the critical $\mathrm{Cu}$ concentration of $2.1-2.3 \mathrm{mg} / \mathrm{kg}$, generally considered the limit for $\mathrm{Cu}$ deficiency, but below the phytotoxic level of $40 \mathrm{mg} / \mathrm{kg}$ for juvenile radiata pine plants (Boardman et al. 1997).

Increasing the soil $\mathrm{Zn}$ concentration decreased needle and root DM yields beyond the $\mathrm{Zn} 1$ treatment (total soil $\mathrm{Zn}>$ $141 \mathrm{mg} / \mathrm{kg}$; Table 1). In roots, a much greater DM yield reduction was observed between the $\mathrm{Zn} 1$ and $\mathrm{Zn} 2$ treatments (from 33.7 to $3.1 \mathrm{~g}$ ) than was observed for needles. Plant needles at the $\mathrm{Zn} 2$ and $\mathrm{Zn} 3$ treatments showed severe drying and yellowing. The DM yield reduction and severe damage of needles caused by the $\mathrm{Zn} 2$ and $\mathrm{Zn} 3$ treatments $(\geq 430 \mathrm{mg} / \mathrm{kg})$ could be well deduced from the severe yellowing and wilting of the pine needles and indicate $\mathrm{Zn}$ toxicity at high levels of $\mathrm{Zn}$ addition. Serious reductions in the needle chlorophyll concentration (manifest as red needles) may lead to reduced $\mathrm{C}$ fixation and thus reduced growth (Ivanov et al. 2011). The data in the current work do not allow pinpointing of the exact cause of the yellowing and reddish coloration in pine needles. However, it is likely that the reduction is largely caused by the $\mathrm{Zn}$-induced impairment of nutrient transfer to needles, in particular $\mathrm{N}, \mathrm{Mg}$ and $\mathrm{Fe}$ which play a key role in chlorophyll synthesis and functioning (Adriaensen et al. 2006). This was probably due to some degree of root damage (Wang et al. 2009) and reduction in root formation (Castiglione et al. 2007) as a consequence of direct contact with a high concentration of bioavailable $\mathrm{Zn}$. The concentration of $\mathrm{Zn}$ in the needles and roots for all $\mathrm{Zn}$ treatments was significantly increased with every successive level of $\mathrm{Zn}$ applied. The needle $\mathrm{Zn}$ concentration above the $\mathrm{Zn} 1$ treatment was much higher than the phytotoxic level of $200 \mathrm{mg} \mathrm{Zn/kg} \mathrm{DM} \mathrm{defined} \mathrm{by}$ Boardman et al. (1997) for juvenile radiata pines. This explains the lower DM yields obtained for the $\mathrm{Zn} 2$ and $\mathrm{Zn} 3$ treatments. The severe DM reduction above the total soil $\mathrm{Zn}$ concentration of $430 \mathrm{mg} / \mathrm{kg}$ ( $\mathrm{Zn} 2$ treatment) tends to support the maximum permissible soil $\mathrm{Zn}$ concentration of $300 \mathrm{mg} / \mathrm{kg}$ set by NZWWA (2003).

The BCF was much lower for $\mathrm{Cu}(0.03-0.26)$ than for $\mathrm{Zn}$ (0.8-1.5; Table 1). The needle/root concentration ratio was also lower for $\mathrm{Cu}$ than for $\mathrm{Zn}$ suggesting that the translocation of $\mathrm{Cu}$ from roots to needles was lower than that for $\mathrm{Zn}$. Copper transport to aboveground plant tissues is generally restricted. Arduini et al. (1996) found during an experiment with 2week-old seedlings of two pine species, with a range of $\mathrm{Cu}$ concentration in solution culture $(0.012-5 \mu \mathrm{M})$, that a maximum $16.5 \%$ of the total root $\mathrm{Cu}$ concentration was accumulated in the shoot and concluded that the root was an effective barrier to $\mathrm{Cu}$ translocation. They also reported that X-ray microanalysis of root tip sections confirmed that $\mathrm{Cu}$ was strongly accumulated in the cell walls of the cortex, where its concentration sharply reduced from outer to inner cell layers. Bücking and Heyser (1994) conducted a study to determine the influence of exposure to five different EDTA extractable $\mathrm{Zn}$ concentrations ranging from 0.3 to $3,000 \mu \mathrm{M}$ for 28 days on Pinus sylvestris root and shoot $\mathrm{Zn}$ concentrations. They observed an increase in "shoot to root $\mathrm{Zn}$ concentration ratio" (1.5-1.8) at low external $\mathrm{Zn}$ concentrations but at high external $\mathrm{Zn}$ concentrations, this ratio decreased drastically $(0.1)$ as observed in our study (Table 1). Although Jeyakumar et al. (2010) also reported that the BCF values were higher for $\mathrm{Zn}$ than $\mathrm{Cu}$ for poplar $(\mathrm{Cu}=0.1-0.8$ and $\mathrm{Zn}=5.5-10)$, their values were much higher than the corresponding values for radiata pine in the current study. This is probably due to the higher translocation and accumulation rate of metals in poplar leaves than radiata pine. Poplar is known to be a shoot metal accumulator plant (Dos Santos Utmazian and Wenzel 2007; Castiglione et al. 2009).

Table 1 Effect of $\mathrm{Cu}$ and $\mathrm{Zn}$ on total soil metal concentration, soil $\mathrm{pH}$, radiata pine metal concentration and DM yield

\begin{tabular}{|c|c|c|c|c|c|c|c|c|c|}
\hline \multirow[t]{2}{*}{ Treatment } & \multicolumn{2}{|c|}{ Total soil metal conc. } & \multirow[t]{2}{*}{$\mathrm{pH}$} & \multicolumn{2}{|c|}{ Dry matter (g) } & \multicolumn{2}{|c|}{ Metal conc. $(\mathrm{mg} / \mathrm{kg})$} & \multirow{2}{*}{$\begin{array}{l}\text { Conc.ratio } \\
\text { Needle: Root }\end{array}$} & \multirow[t]{2}{*}{$\mathrm{BCF}$} \\
\hline & Solid $^{\mathrm{a}}(\mathrm{mg} / \mathrm{kg})$ & Solution (mg/L) & & Needle & Root & Needle & Root & & \\
\hline $\mathrm{Cu} 0$ & 16 & $0.03 \mathrm{c}$ & $6.1 \mathrm{a}$ & $72.3 \mathrm{a}$ & $34.8 \mathrm{a}$ & $4.2 \mathrm{~d}$ & $10 \mathrm{~d}$ & $0.42 \mathrm{a}$ & $0.26 \mathrm{a}$ \\
\hline $\mathrm{Cu} 1$ & 48 & $0.27 \mathrm{~b}$ & $5.8 \mathrm{ab}$ & $67.5 \mathrm{a}$ & $32.7 \mathrm{a}$ & $5.3 \mathrm{c}$ & $65 \mathrm{c}$ & $0.08 \mathrm{~b}$ & $0.11 \mathrm{~b}$ \\
\hline $\mathrm{Cu} 2$ & 146 & $0.37 \mathrm{~b}$ & $5.7 \mathrm{~b}$ & $65.6 \mathrm{a}$ & $35.6 \mathrm{a}$ & $6.3 \mathrm{~b}$ & $166 \mathrm{~b}$ & $0.04 \mathrm{~b}$ & $0.04 \mathrm{c}$ \\
\hline $\mathrm{Cu} 3$ & 232 & $0.54 \mathrm{a}$ & $5.7 \mathrm{~b}$ & $65.0 \mathrm{a}$ & $39.6 \mathrm{a}$ & $7.3 \mathrm{a}$ & $267 \mathrm{a}$ & $0.03 \mathrm{~b}$ & $0.03 \mathrm{c}$ \\
\hline $\mathrm{Zn} 0$ & 36 & $0.9 \mathrm{c}$ & $6.1 \mathrm{a}$ & $72.3 \mathrm{a}$ & $34.8 \mathrm{a}$ & $39 \mathrm{~d}$ & $45 \mathrm{~d}$ & $0.85 \mathrm{a}$ & $1.08 \mathrm{ab}$ \\
\hline $\mathrm{Zn} 1$ & 141 & $4.4 \mathrm{c}$ & $5.5 \mathrm{~b}$ & $68.1 \mathrm{a}$ & $33.7 \mathrm{a}$ & $205 \mathrm{c}$ & $550 \mathrm{c}$ & $0.37 \mathrm{~b}$ & $1.45 \mathrm{a}$ \\
\hline $\mathrm{Zn} 2$ & 430 & $89 \mathrm{~b}$ & $4.8 \mathrm{c}$ & $33.5 \mathrm{~b}$ & $3.1 \mathrm{~b}$ & $341 \mathrm{~b}$ & $2,464 \mathrm{~b}$ & $0.14 \mathrm{c}$ & $0.79 \mathrm{~b}$ \\
\hline $\mathrm{Zn} 3$ & 668 & $362 \mathrm{a}$ & $4.7 \mathrm{c}$ & $12.6 \mathrm{c}$ & $1.5 \mathrm{~b}$ & $1,000 \mathrm{a}$ & $5,033 \mathrm{a}$ & $0.20 \mathrm{c}$ & $1.50 \mathrm{a}$ \\
\hline
\end{tabular}

Values in columns followed by different letters are significantly different $(P \leq 0.05)$

$B C F$ bioconcentration factor

${ }^{\text {a }}$ Original biosolid-treated soil 
Metal speciation in soil solution phase

The total metal concentrations in soil solution obtained in the present study indicate that increased total soil metal concentrations have increased soil solution metal concentrations (Table 1). When the soil solution $\mathrm{Cu}$ speciation was investigated using the WHAM speciation model, the $\mathrm{Cu}^{2+}$ concentrations (in micromolar) in soil solution were $0.001,0.008,0.040$ and 0.060 for the $\mathrm{Cu} 0, \mathrm{Cu} 1, \mathrm{Cu} 2$ and $\mathrm{Cu} 3$ treatments, respectively. The free copper ion concentration contributed a maximum $1 \%$ of the soil solution $\mathrm{Cu}$ (Table 2). The low $\mathrm{Cu}^{2+}$ concentration for all treatments is attributed to about $99 \%$ of $\mathrm{Cu}$ in soil solution being complexed to dissolved organic carbon (DOC). This is because $\mathrm{Cu}$ forms very strong complexes with DOC through chelation with constituent functional groups such as carboxylic acids, amines and phenols (Altun and Köseoĝlu 2005). Furthermore, the stability of these complexes is higher than Zn (Pandey et al. 2000). Strobel et al. (2001) reported that $\mathrm{Cu}$ belongs to a group of elements that have strong interactions with DOC in the $\mathrm{pH}$ range 4-7. In our study, the $\mathrm{pH}$ values for all $\mathrm{Cu}$ treatments ranged from 5.7 to 6.1 , and therefore we expect $\mathrm{Cu}$ in soil solution to have strongly complexed to DOC. As there are no published data available on soil solution $\mathrm{Cu}$ speciation and its relationship to pine growth, hydroponic studies are used to explain the $\mathrm{Cu}^{2+}$ concentration effect on pine growth. As hydroponic solutions have no dissolved organic matter for complexation of $\mathrm{Cu}$, approximately all $\mathrm{Cu}$ in hydroponic solution is expected to exist as $\mathrm{Cu}^{2+}$ and therefore the total $\mathrm{Cu}$ concentration in hydroponic solution can be assumed to be the $\mathrm{Cu}^{2+}$ concentration. Van Tichelen et al. (2001) carried out a trial with ectomycorrhizal (ECM)-inoculated Scot pine seedlings grown in hydroponics solution and reported that even at a $\mathrm{Cu}$ concentration of $47 \mu \mathrm{M}$, shoot $\mathrm{Cu}$ concentration was $<25 \mathrm{mg} / \mathrm{kg}$. In another study, Fuentes et al. (2007b) conducted an experiment with seedlings of several Mediterranean woody species (Pinus halepensis, Pistacia lentiscus, Juniperus oxycedrus and Rhamnus alaternus) in a hydroponic culture for 12 weeks. They reported that increasing the nutrient solution $\mathrm{Cu}$ concentration from 0.047 to $1 \mu \mathrm{M} \mathrm{Cu}$ increased the pine biomass DM, but at $4 \mu \mathrm{M} \mathrm{Cu}$ the shoot and root biomass were decreased by 27 and $33 \%$, respectively, as compared to the $1 \mu \mathrm{M} \mathrm{Cu}$ treatment. In the present trial with radiata pine, the maximum $\mathrm{Cu}^{2+}$ concentration in soil solution was $0.06 \mu \mathrm{M}$ showing that even at an elevated treatment level (Cu3), bioavailable $\mathrm{Cu}$ was low. Even though the $\mathrm{Cu}^{2+}$ concentrations were low for all treatments, the $\mathrm{Cu}$ concentration in needle was above the critical level for $\mathrm{Cu}$ deficiency in radiata pine. Therefore, the plants were taking up $\mathrm{Cu}$ from soil $\mathrm{Cu}$ fractions other than $\mathrm{Cu}^{2+}$, and there must be other factors influencing the $\mathrm{Cu}$ uptake. Zhao et al. (2006) studied $\mathrm{Cu}$ toxicity in tomato plants in 18 European soils and found that free $\mathrm{Cu}^{2+}$ activity alone was a poor predictor of the $\mathrm{Cu}$ concentrations in tomato roots and shoots. They concluded that bioavailability in soil depended on the combined effects of $\mathrm{Cu}$ speciation, interaction with protective ions such as $\mathrm{H}+$, and $\mathrm{Cu}$ resupply from the solid phase. In a greenhouse study with ryegrass, Luo and Christie (1997) similarly concluded that shoot $\mathrm{Cu}$ concentration may not depend solely upon labile soil solution $\mathrm{Cu}$ concentration, and that uptake is also influenced by solid phase $\mathrm{Cu}$ fractions.

The soil solution $\mathrm{Zn}^{2+}$ concentrations (in micromolar) for the $\mathrm{Zn} 0, \mathrm{Zn} 1, \mathrm{Zn} 2$ and $\mathrm{Zn} 3$ treatments were 4.5, 41, 983 and 4, 419 , respectively; and contributed $32-80 \%$ of total $\mathrm{Zn}$ in the soil solution (Table 2). Fuentes et al. (2007b) also examined the effect of $\mathrm{Zn}$ on pine seedlings ( $P$. halepensis) in hydroponic culture and reported that by increasing the solution $\mathrm{Zn}$ concentration from 0.073 to $25 \mu \mathrm{M} \mathrm{Zn}$, pine seedling DM was increased. However, at $100 \mu \mathrm{M} \mathrm{Zn}$, shoot and root biomass was decreased by 35 and $24 \%$, respectively relative to the $25 \mu \mathrm{M} Z \mathrm{n}$ concentration. Considering these experimental results along with data from the present trial with radiata pines, we can hypothesise that the $\mathrm{Zn}$ treatment above the $\mathrm{Zn} 1$ level may be phytotoxic to the pine seedlings. This confirms the observed effect on DM yield and needle $\mathrm{Zn}$ concentration resulting from an increasing $\mathrm{Zn}$ concentration in the soil. The critical phytotoxic level of $\mathrm{Zn}$ in soil solution for the current study was determined by fitting a curve that relates DM content to the $\mathrm{Zn}^{2+}$ concentration in soil solution (Fig. 1). Assuming that $10 \% \mathrm{DM}$ yield reduction is an indicator of $Z n$ toxicity (Reichman et al. 2001), Fig. 1 derives a critical $\mathrm{Zn}^{2+}$ concentration for $\mathrm{Zn}$ toxicity of $62 \mu \mathrm{M}$. In
Table 2 Percentage of metal (M) species in soil solution (organic $\mathrm{M}$ calculated by subtracting the total concentration of inorganic species from the corresponding total metal concentration)

Values are means \pm standard error, $n=3$ (in parenthesis)

\begin{tabular}{lrllllr}
\hline & $\mathrm{M}^{2+}$ & $\mathrm{MHCO}_{3}$ & \multicolumn{1}{l}{$\mathrm{MSO}_{4}$} & $\mathrm{MCl}$ & \multicolumn{1}{l}{ Total } & Organic M \\
\hline $\mathrm{Cu} 0$ & $0.01(0.00)$ & $0.00(0.00)$ & $0.00(0.00)$ & $0.00(0.00)$ & $0.01(0.00)$ & $99.99(1.89)$ \\
$\mathrm{Cu} 1$ & $0.20(0.02)$ & $0.01(0.00)$ & $0.07(0.01)$ & $0.00(0.00)$ & $0.28(0.3)$ & $99.72(1.34)$ \\
$\mathrm{Cu} 2$ & $0.75(0.10)$ & $0.03(0.01)$ & $0.22(0.02)$ & $0.00(0.00)$ & $1.00(0.12)$ & $99.00(2.01)$ \\
$\mathrm{Cu} 3$ & $0.73(0.10)$ & $0.02(0.00)$ & $0.28(0.03)$ & $0.00(0.00)$ & $1.04(0.10)$ & $98.96(1.64)$ \\
$\mathrm{Zn} 0$ & $31.65(1.44)$ & $0.09(0.01)$ & $5.73(0.24)$ & $0.02(0.00)$ & $37.48(1.23)$ & $62.52(1.08)$ \\
$\mathrm{Zn} 1$ & $61.15(1.51)$ & $0.04(0.01)$ & $16.79(0.64)$ & $0.15(0.02)$ & $78.14(1.51)$ & $21.86(0.86)$ \\
$\mathrm{Zn} 2$ & $72.24(1.47)$ & $0.01(0.00)$ & $27.92(1.03)$ & $0.19(0.02)$ & $100.36(2.02)$ & $0.00(0.00)$ \\
$\mathrm{Zn} 3$ & $79.83(1.54)$ & $0.01(0.00)$ & $21.36(1.12)$ & $0.20(0.03)$ & $101.41(2.10)$ & $0.00(0.00)$ \\
\hline
\end{tabular}




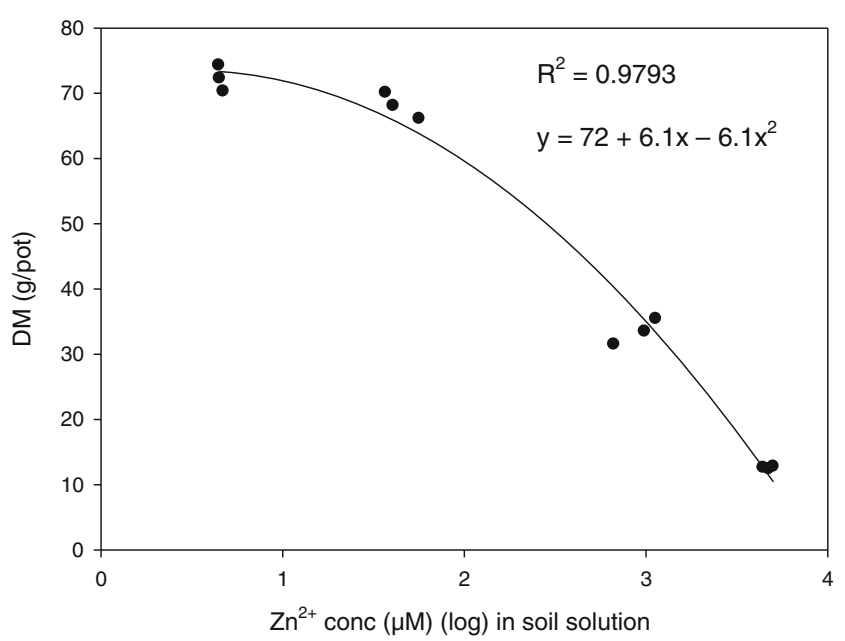

Fig. 1 Relationship of radiata pine needle DM with the $\mathrm{Zn}^{2+}$ concentration (in micromolar) in soil solution

previous hydroponics experiments, $40 \mu \mathrm{M} \mathrm{Zn}$ has been shown to cause a reduction in root elongation for grasses which are sensitive to Zn stress (Al-Hiyaly et al. 1988), while $76 \mu \mathrm{M} \mathrm{Zn}$ reduced the growth as well as the $\mathrm{N}$ and $\mathrm{P}$ uptake capacity of Zn-sensitive ECM (Suillus bovinus) associated with pine seedlings (Adriaensen et al. 2004). The critical Zn concentration for $\mathrm{Zn}$ toxicity in this study also agrees with our previous study with poplar (Jeyakumar et al. 2010) where $88.5 \mu \mathrm{M}$ $\mathrm{Zn}^{2+}$ caused a reduction in DM yield of leaves.

The considerable percentage of $\mathrm{ZnSO}_{4}$ species (6-28 \%) observed in soil solution is due to the use of sulphate salts of the metals in the spiking of biosolids (Jeyakumar et al. 2008). Metal carbonate and chloride concentrations were negligibly small for both metals at all levels.

Metal fractionation in the soil solid phase

The percentage distribution of $\mathrm{Cu}$ and $\mathrm{Zn}$ in the various soil solid-phase fractions was measured to determine the fate of added metals and to explain the bioavailability and potential phytotoxicity of $\mathrm{Zn}$ and $\mathrm{Cu}$ derived from the biosolids (Fig. 2). Further, the degree of bioavailability associated with nonbioavailable fractions can be better interpreted by means of expressing fractionation in percentage. Copper ions generally have a strong affinity with soil organic matter (SOM; Stevenson 1991). Therefore, organic fraction in the soil can be the most important factor in determining $\mathrm{Cu}$ bioavailability (del Castilho et al. 1993). However, $\mathrm{Zn}$ ions have less affinity with SOM than $\mathrm{Cu}$ (McLaren and Clucas 2001).

When the soil $\mathrm{Cu}$ level was low, the residual fraction was the largest contribution to total soil $\mathrm{Cu}$ ( 43 and $34 \%$ for the $\mathrm{Cu} 0$ and $\mathrm{Cu} 1$ treatments, respectively), followed by oxidebound $\mathrm{Cu}$ fraction (21-42\%) and specifically sorbed $\mathrm{Cu}(19$ and $11 \%$ for $\mathrm{Cu} 0$ and $\mathrm{Cu} 1$ treatments, respectively). Howev$\mathrm{er}$, as the $\mathrm{Cu}$ level increased, the relative contribution of the various fractions changed. The residual fraction significantly reduced (13-17\%), whereas the percentage of $\mathrm{Cu}$ associated with the oxide fraction (52-54\%) increased at higher $\mathrm{Cu}$ levels $(\mathrm{Cu} 2$ and $\mathrm{Cu} 3)$. The increase in organic bound $\mathrm{Cu}$ was from 5 to $11 \%$, as the $\mathrm{Cu}$ levels increased. The soluble + exchangeable $\mathrm{Cu}$ fraction for the control treatment contributed $12 \%$ to total soil copper, but in the biosolidsamended soils (from $\mathrm{Cu} 1$ to $\mathrm{Cu} 3$ ), was reduced to $5-8 \%$ of the total $\mathrm{Cu}$ concentration. The differences were not significant among the $\mathrm{Cu}$ treatments. These results show that increasing the level of $\mathrm{Cu}$ changed the relative percentage of $\mathrm{Cu}$ among the non-bioavailable $\mathrm{Cu}$ fractions, but did not significantly change the percentage of $\mathrm{Cu}$ associated with the bioavailable soluble + exchangeable fraction in the soil. However, the absolute concentration of soluble + exchangeable $\mathrm{Cu}$ in the solid-phase increased with an increase in $\mathrm{Cu}$ levels $(2,2,11$ and $13 \mathrm{mg} / \mathrm{kg}$ soil for the $\mathrm{Cu} 0, \mathrm{Cu} 1, \mathrm{Cu} 2$ and $\mathrm{Cu} 3$ treatments, respectively). The increase in the percentage of $\mathrm{Cu}$ in the oxide fractions is probably due to strong sorption of the added $\mathrm{Cu}$ to the oxide constituents of the soil. Perhaps with time the sorbed $\mathrm{Cu}$ may move to the residual fraction by diffusion into lattice structures (McBride 1991), and this would lead to an increased percentage of copper associated with the residual fraction as observed in the native soil ( $\mathrm{Cu} 0$ treatment).
Fig. 2 Percentage distribution of $\mathrm{Cu}$ and $\mathrm{Zn}$ fractionation in rhizosphere and bulk soils amended with biosolids under radiata pine

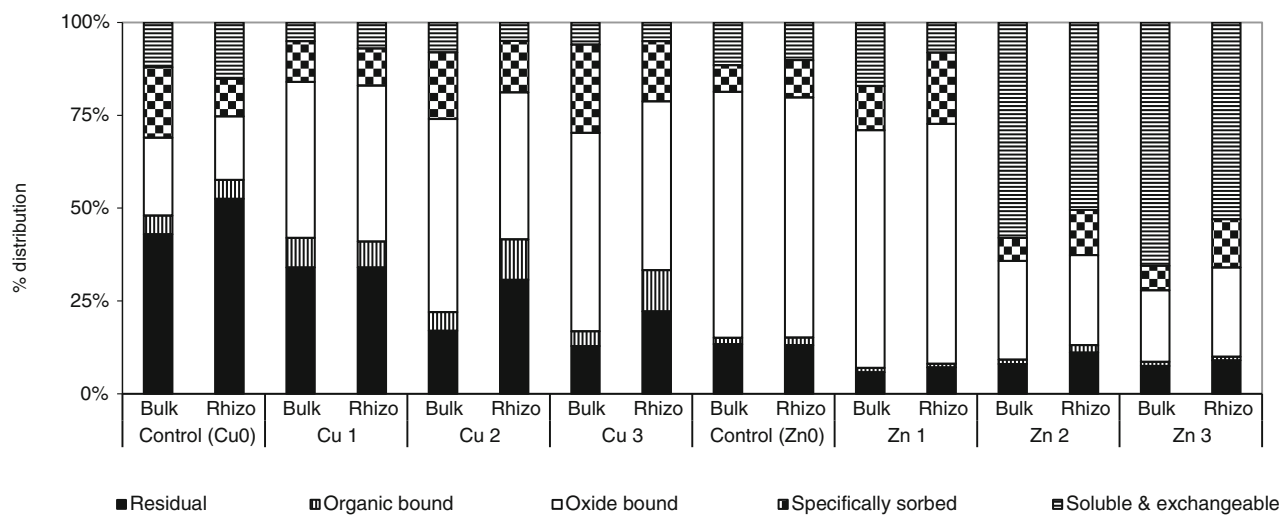


Huang et al. (2008) conducted an experiment with ECMinoculated Chinese pine seedlings grown in a brown soil amended with $\mathrm{Cu}(25-400 \mathrm{mg} / \mathrm{kg}$ soil), and reported that the percentage of $\mathrm{Cu}$ associated with the non-labile soil $\mathrm{Cu}$ fractions increased with increasing total soil $\mathrm{Cu}$ concentration (carbonate fraction from 23 to $57 \%$, oxide fraction from 24 to $31 \%$ and residual fraction from 11 to $23 \%$ ), but the percentage of $\mathrm{Cu}$ associated with the soluble+exchangeable fraction was reduced (from 8 to $1 \%$ ). Consistent with these results, in our study the percentage of soluble+exchangeable $\mathrm{Cu}$ concentration reduced from $12 \%$ for the no- $\mathrm{Cu}$ treatment to $5 \%$ for the highest $\mathrm{Cu}$ treatment. Our data infers that the increasing amount of $\mathrm{Cu}$ added to the soil was mainly associated with non-labile forms.

The relative distribution of the $\mathrm{Zn}$ fractions was different to that of $\mathrm{Cu}$ (Fig. 2). The percentage of organic-bound $\mathrm{Zn}$ was much lower (1-2\%) than that for $\mathrm{Cu}(5-11 \%)$. For low levels of total soil $\mathrm{Zn}(\mathrm{Zn} 0$ and $\mathrm{Zn} 1)$, the percentage of oxide-bound metal was higher (64-66\%) than for the high levels of soil $\mathrm{Zn}$ (19-26\%), whereas at the higher rates ( $\mathrm{Zn} 2$ and $\mathrm{Zn} 3$ ) the $\mathrm{Zn}$ was mostly present in the soluble + exchangeable fraction (58$66 \%$ ). The bioavailability of $\mathrm{Zn}$ as a proportion of the total $\mathrm{Zn}$ in soil, up to the $\mathrm{Zn} 1$ level, was low, as indicated by the relatively low contribution of the soluble + exchangeable fraction to total soil $\mathrm{Zn}(12-17 \%$ up to $\mathrm{Zn} 1)$. But at higher rates ( $\mathrm{Zn} 2$ and $\mathrm{Zn} 3$ ) added $\mathrm{Zn}$ significantly increased $\mathrm{Zn}$ availability and caused toxicity to the plant tissues. The absolute concentrations of soluble + exchangeable $\mathrm{Zn}$ in the $\mathrm{Zn} 0, \mathrm{Zn} 1, \mathrm{Zn} 2$ and $\mathrm{Zn} 3$ treatments were 4, 32, 249 and $437 \mathrm{mg} / \mathrm{kg}$, respectively. Reduced plant $\mathrm{DM}$ content and increasing needle $\mathrm{Zn}$ concentration as a function of $\mathrm{Zn}$ amendment is consistent with these results. The lower soil $\mathrm{pH}$ range $(4.4-4.8)$ for the $\mathrm{Zn} 2$ and $\mathrm{Zn} 3$ treatments relative to the $\mathrm{Zn} 0$ and $\mathrm{Zn} 1$ treatments (pH 5.6-6.1) could have reduced the sorption of $\mathrm{Zn}$ to soil organic matter and minerals through a reduction in net negative charge on soil components (McBride 1991). This would have led to a higher percentage of $\mathrm{Zn}$ in the soluble+exchangeable fractions at higher levels of $\mathrm{Zn}$ treatment. The rhizosphere soils did not show any significant difference in $\mathrm{Zn}$ fractionation relative to the bulk soil. This may be due to poor separation of rhizosphere soil from bulk soil because the root density in the pots was very high.

The lower soil solution and soluble+exchangeable solidphase $\mathrm{Cu}$ concentrations relative to the corresponding $\mathrm{Zn}$ concentrations as also found for metals amended biosolids by McLaren and Clucas (2001) and soils (Kunito et al. 2001) explain the lack of apparent phytotoxicity of $\mathrm{Cu}$, but obvious phytotoxicity of $\mathrm{Zn}$ to radiata pine growth in the current study. These observations are in agreement with those made by Jeyakumar et al. (2010) for poplar under similar growth conditions.
Dehydrogenase activity

The rhizosphere soils did not show any significant difference in dehydrogenase activity relative to the bulk soil. Even though $\mathrm{Cu}$ was not found to be toxic to plants, it was found to be toxic to soil microorganisms at all levels of $\mathrm{Cu}$ addition, as observed from the decrease in soil dehydrogenase activity with increasing $\mathrm{Cu}$ concentration (Fig. 3).

The effect of $\mathrm{Zn}$ on soil microorganisms was the same as that for $\mathrm{Cu}$; increasing the rate of $\mathrm{Zn}$ decreased soil dehydrogenase activity at all levels of $\mathrm{Zn}$ addition. However, $\mathrm{Zn}$ addition also reduced plant growth (Table 1). A reduction in dehydrogenase activity affected by both $\mathrm{Cu}$ and $\mathrm{Zn}$ was also found by Jeyakumar et al. (2010) for similar concentrations of total $\mathrm{Cu}$ and $\mathrm{Zn}$ in soil. The decrease in dehydrogenase activity relative to the control was greater for $\mathrm{Zn}$ than $\mathrm{Cu}$, as has also been found by others (Kunito et al. 2001; Broos et al. 2007). This is because of the much higher increase in bioavailable $\mathrm{Zn}$ (soil solution and exchangeable $\mathrm{Zn}$ ) compared to $\mathrm{Cu}$ which was largely complexed by DOC and soil organic matter. However, toxicity per unit soil solution or exchangeable $\mathrm{Cu}$ was greater for $\mathrm{Cu}$ as explained in the following paragraph.

The dehydrogenase activity data were correlated with solution-phase and soluble + exchangeable solid-phase metal concentrations. The concentration of metal in the solutionphase and in the soluble + exchangeable solid-phase that corresponded to a $50 \%$ reduction in dehydrogenase activity $\left(\mathrm{EC}_{50}\right)$ was determined. For $\mathrm{Cu}$, the $\mathrm{EC}_{50}$ values were not able to be determined because there were insufficient data points at high $\mathrm{Cu}$ concentrations. Therefore, $\mathrm{EC}_{40}$ values $(\mathrm{Cu}$ concentration corresponding to $40 \%$ reduction in dehydrogenase activity which is equivalent to $60 \%$ activity in Fig. 4) were calculated. The $\mathrm{EC}_{40}$ values for solution-phase and for soluble+exchangeable solid-phase $\mathrm{Cu}$ were $0.5 \mathrm{mg} / \mathrm{L}$ and $14.5 \mathrm{mg} / \mathrm{kg}$, respectively. The $\mathrm{EC}_{50}$ values for solution-phase and for soluble + exchangeable solid-phase $\mathrm{Zn}$ were $9 \mathrm{mg} / \mathrm{L}$ and $55 \mathrm{mg} / \mathrm{kg}$, respectively (Fig. 4). The $\mathrm{EC}_{40}$ values for corresponding species for $\mathrm{Zn}$ were $5 \mathrm{mg} / \mathrm{L}$ and $33 \mathrm{mg} / \mathrm{kg}$, respectively. The lower $\mathrm{EC}$ values for $\mathrm{Cu}$ than for $\mathrm{Zn}$ indicate that $\mathrm{Cu}$ is more toxic for microbial activity. This may suggest that the intra- and extracellular enzymes functioning in the microorganisms is more sensitive to excessive $\mathrm{Cu}$ than $\mathrm{Zn}$ despite the higher soil solution concentrations of the latter (Hartikainen et al. 2012).

Where relative toxicity of $\mathrm{Cu}$ and $\mathrm{Zn}$ is ascribed to the total metal concentration in soil, $\mathrm{Zn}$ has a greater toxic effect on soil microbial activity than $\mathrm{Cu}$ (Fig. 3). This statement is validated through consideration of soil dehydrogenase activity as a function of $\mathrm{Cu}$ and $\mathrm{Zn}$ at the same total soil metal concentration. Comparison of TPF for the $\mathrm{Cu} 2(146 \mathrm{mg} \mathrm{Cu} / \mathrm{kg})$ and $\mathrm{Zn} 1(141 \mathrm{mg} \mathrm{Zn} /$ $\mathrm{kg}$ ) treatment shows that microbial activity was lower 
Fig. 3 Dehydrogenase activity (TPF) in bulk and rhizosphere soils at different levels of $\mathrm{Cu}$ and $\mathrm{Zn}$. Bars with different letters are significantly different $(P \leq 0.05)$. Simple letters indicate the variance among the bulk soils and capital letters are the rhizosphere soils

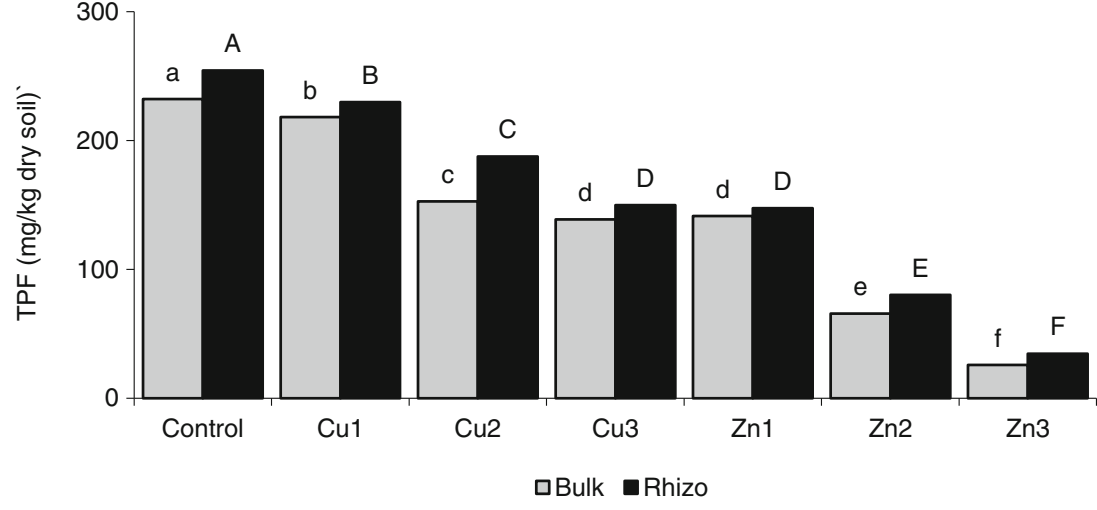

for $\mathrm{Zn}$ than $\mathrm{Cu}$. However, when the metal concentration is expressed in terms of bioavailable soil metal (soil solution and the soluble+exchangeable fraction), the toxicity of $\mathrm{Zn}$ was lower than that of $\mathrm{Cu}$ (quantified as a higher $\mathrm{EC}_{40}$ value of $\mathrm{Zn}$ than $\mathrm{Cu}$; Fig. 4). This difference illustrates variations in bioavailability between $\mathrm{Cu}$ and $\mathrm{Zn}$ relative to total soil metal concentrations. This differential effect highlights the importance of carefully interpreting results of the toxicity of $\mathrm{Cu}$ and $\mathrm{Zn}$ on microbial activity. Broos et al. (2007) estimated the $\mathrm{Cu}$ and $\mathrm{Zn} \mathrm{EC}_{50}$ concentration values for substrateinduced nitrification and respiration activities in 12 soils previously amended with $\mathrm{Zn}(5-9,100 \mathrm{mg} / \mathrm{kg})$ and $\mathrm{Cu}$
$(3-5,880 \mathrm{mg} / \mathrm{kg})$ that were collected in fields from various parts of Australia. They concluded that when the $\mathrm{EC}_{50}$ values were based on a total metal concentration, there was a strong 1:1 relationship between $\mathrm{EC}_{50}$ values for $\mathrm{Cu}$ and $\mathrm{Zn}$ across all soils, indicating equal microbial toxicity of these metals in soil. However, when $\mathrm{EC}_{50}$ values were based on the soil solution concentration, $\mathrm{Cu}$ generally was more toxic (lower $\mathrm{EC}_{50}$ ) than $\mathrm{Zn}$ as observed in the current study. These results indicate the importance and reliability of interpreting the toxic effects of metals in terms of their bioavailability as measured by metal concentration in soil solution rather than the total metal concentration associated with soil particles.
Fig. 4 Relationship of dehydrogenase activity (TPF) with a soil solution $\mathrm{Cu}, \mathbf{b}$ soluble+exchangeable $\mathrm{Cu}, \mathbf{c}$ soil solution $\mathrm{Zn}$ and $\mathbf{d}$ soluble+ exchangeable $\mathrm{Zn}$ a

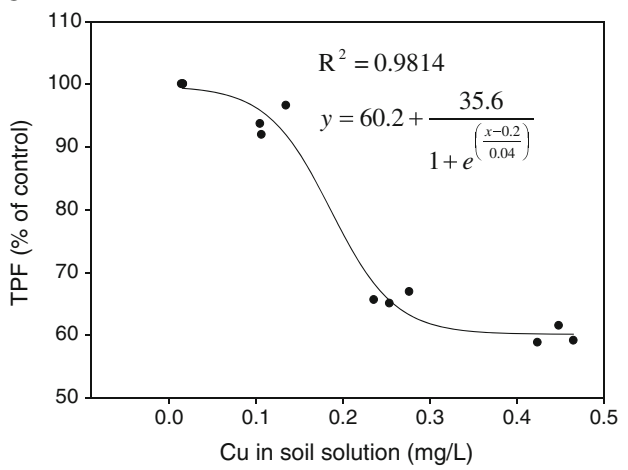

C

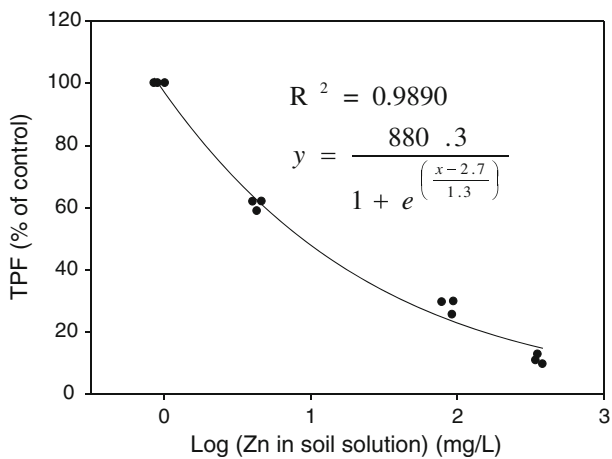

b

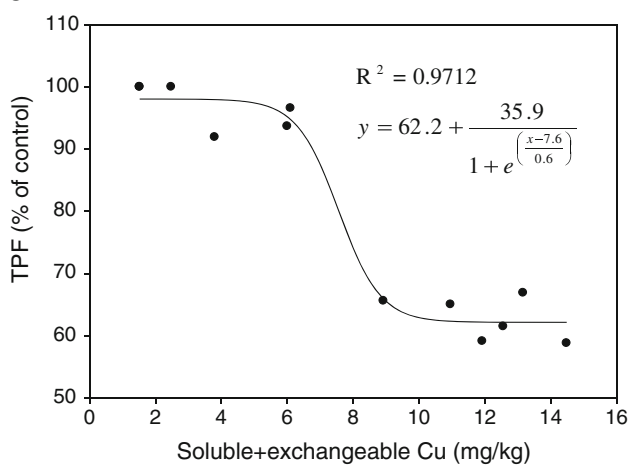

d

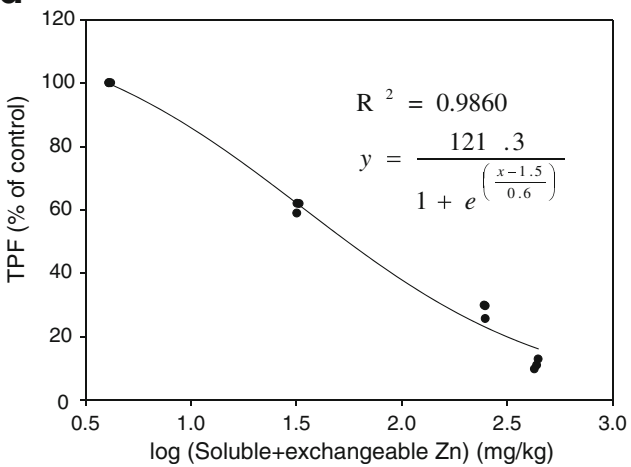




\section{Conclusion and recommendations}

An increasing amount of $\mathrm{Cu}$ applied to soil in the form of $\mathrm{Cu}$ amended biosolids increased the concentration of $\mathrm{Cu}$ in radiata pine needle, but had no effect on needle and root DM production, even at the highest total soil concentration of $232 \mathrm{mg} / \mathrm{kg}$. However, the effect of $\mathrm{Zn}$ was varied when an increasing amount of $\mathrm{Zn}$ was applied to soil in the form of $\mathrm{Zn}$ amended biosolids. A severe phytotoxic effect was observed when the total soil $\mathrm{Zn}$ concentration exceeded $141 \mathrm{mg} / \mathrm{kg}$. $\mathrm{Cu}$ was not phytotoxic because the $\mathrm{Cu}^{2+}$ concentration in soil solution was extremely low $(0.06 \mu \mathrm{M})$ due to most of the solution $\mathrm{Cu}$ being complexed to dissolved organic matter (approximately $99 \%$ ). The phytotoxic effect of $\mathrm{Zn}$ was due to a high $\mathrm{Zn}^{2+}$ concentration in soil solution (41-4419 $\mu \mathrm{M}$, $61-80 \%$ of soil solution $\mathrm{Zn}$ ). The critical concentration value for phytotoxicity was calculated to be $62 \mu \mathrm{M} \mathrm{Zn}^{2+}$. In addition, soil metal fractionation showed that the total $\mathrm{Cu}$ concentration in the soluble + exchangeable $\mathrm{Cu}$ fraction $(2-13 \mathrm{mg} \mathrm{Cu} /$ $\mathrm{kg}$ soil; $5-12 \%$ of total $\mathrm{Cu}$ ) was significantly lower than that for $\mathrm{Zn}$ (4-437 mg Zn/kg; 12-66 \% of total $\mathrm{Zn}$ ) suggesting that the bioavailable solid-phase $\mathrm{Zn}$ may have also contributed to $\mathrm{Zn}$ phytotoxicity to radiata pine. The lower bioavailability of $\mathrm{Cu}$ resulted in a lower BCF value for $\mathrm{Cu}(0.03-0.26)$ compared with that for $\mathrm{Zn}(0.8-1.5)$. Translocation of $\mathrm{Cu}$ from root to needle was also lower than that for $\mathrm{Zn}$ as indicated by the lower needle/root ratio for $\mathrm{Cu}$ relative to $\mathrm{Zn}$.

Soil microbial activity was inhibited by both $\mathrm{Cu}$ and $\mathrm{Zn}$ at all levels of metal addition. The rate of reduction relative to the control was greater for $\mathrm{Zn}$ than for $\mathrm{Cu}$. $\mathrm{EC}_{40}$ for $\mathrm{Cu}$ for solutionphase and soluble + exchangeable solid-phase was calculated to be $0.5 \mathrm{mg} / \mathrm{L}$ and $14.5 \mathrm{mg} / \mathrm{kg}$, respectively. For $\mathrm{Zn}$, the corresponding $\mathrm{EC}_{50}$ values were $9 \mathrm{mg} / \mathrm{L}$ and $55 \mathrm{mg} / \mathrm{kg}$.

In summary at similar rates of total soil metal concentration, $\mathrm{Cu}$ was not phytotoxic to radiata pine, but $\mathrm{Zn}$ was. Both $\mathrm{Cu}$ and $\mathrm{Zn}$ showed the same toxicity trend to soil microbial activity. With respect to commercial pine forestry, we propose that the current recommended limits for the total $\mathrm{Cu}$ and $\mathrm{Zn}$ concentration in New Zealand soil (100 mg/kg for $\mathrm{Cu} ; 300 \mathrm{mg} / \mathrm{kg}$ for $\mathrm{Zn}$ ) are too high for soil microbial activity. With respect to phytotoxicity, we recommend that the total $\mathrm{Zn}$ concentration limit in soils be revised downwards as the present limit exceeds the upper critical toxicity level to radiata pine.

\section{References}

Adriaensen K, Van Der Lelie D, Van Laere A, Vangronsveld J, Colpaert JV (2004) A zinc-adapted fungus protects pines from zinc stress. New Phytol 161:549-555

Adriaensen K, Vangronsveld J, Colpaert J (2006) Zinc-tolerant Suillus bovinus improves growth of $\mathrm{Zn}$-exposed Pinus sylvestris seedlings. Mycorrhiza 16:553-558
Al-Hiyaly SA, McNeilly T, Bradshaw AD (1988) The effects of zinc contamination from electricity pylons-evolution in a replicated situation. New Phytol 110:571-580

Alloway BJ (1995) Soil processes and the behaviour of heavy metals. In: Alloway BJ (ed) Heavy metals in soils, 2nd edn. Blackie, London, pp 11-37

Altun Y, Köseoĝlu F (2005) Stability of copper(II), nickel(II) and zinc(II) binary and ternary complexes of histidine, histamine and glycine in aqueous solution. J Solut Chem 34:213-231

Arduini I, Godbold DL, Onnis A (1996) Cadmium and copper uptake and distribution in Mediterranean tree seedlings. Physiol Plant 97:111-117

Boardman R, Cromer RN, Lambert MJ, Webb MJ (1997) Forest plantations. In: Reuter DJ, Robinson JB (eds) Plant analysis: an interpretation manual. CSIRO, Melbourne, pp 505-566

Broos K, Warne MSJ, Heemsbergen DJ, Stevens D, Barnes MB, Correll RL, McLaughlin MJ (2007) Soil factors controlling the toxicity of copper and zinc to microbial processes in Australian soils. Environ Toxicol Chem 26:583-590

Bücking H, Heyser W (1994) The effect of ectomycorrhizal fungi on Zn uptake and distribution in seedlings of Pinus sylvestris L. Plant Soil 167:203-212

Castiglione S, Franchin C, Fossati T, Lingua G, Torrigiani P, Biondi S (2007) High zinc concentrations reduce rooting capacity and alter metallothionein gene expression in white poplar (Populus alba $\mathrm{L}$. cv. Villafranca). Chemosphere 67:1117-1126

Castiglione S, Todeschini V, Franchin C, Torrigiani P, Gastaldi D, Cicatelli A, Rinaudo C, Berta G, Biondi S, Lingua G (2009) Clonal differences in survival capacity, copper and zinc accumulation, and correlation with leaf polyamine levels in poplar: a large-scale field trial on heavily polluted soil. Environ Pollut 157:2108-2117

Centre for Ecology and Hydrology (2002) Windermere humic aqueous model (WHAM): equilibrium chemical speciation for natural waters. Natural Environmental Research Council, Wallingford

Chander K, Brookes PC (1991) Is the dehydrogenase assay invalid as a method to estimate microbial activity in copper-contaminated soils? Soil Biol Biochem 23:909-915

del Castilho P, Chardon WJ, Salomons W (1993) Influence of cattle-manure slurry application on the solubility of cadmium, copper, and zinc in a manured acidic, loamy-sand soil. J Environ Qual 22:689-697

Dos Santos Utmazian MN, Wenzel WW (2007) Cadmium and zinc accumulation in willow and poplar species grown on polluted soils. J Plant Nutr Soil Sci 170:265-272

Egiarte G, Pinto M, Ruiz-Romera E, Arbestain MC (2009) Changes in heavy metal concentrations in acid soils under pine stands subjected to repeated applications of biosolids. Soil Sci 174:372-379

Ferreiro-Dominguez N, Rigueiro-Rodriguez A, Mosquera-Losada MR (2012) Sewage sludge fertilizer use: implications for soil and plant copper evolution in forest and agronomic soils. Sci Total Environ 424:39-47

Fuentes D, Disante KB, Valdecantos A, Cortina J, Ramón Vallejo V (2007a) Response of Pinus halepensis Mill. seedlings to biosolids enriched with $\mathrm{Cu}, \mathrm{Ni}$ and $\mathrm{Zn}$ in three Mediterranean forest soils. Environ Pollut 145:316-323

Fuentes D, Disante KB, Valdecantos A, Cortina J, Vallejo VR (2007b) Sensitivity of Mediterranean woody seedlings to copper, nickel and zinc. Chemosphere 66:412-420

Giller KE, Witter E, McGrath SP (1998) Toxicity of heavy metals to microorganisms and microbial processes in agricultural soils: a review. Soil Biol Biochem 30:1389-1414

Gratton WS, Nkongolo KK, Spiers GA (2000) Heavy metal accumulation in soil and jack pine (Pinus banksiana) needles in Sudbury, Ontario, Canada. Bull Environ Contam Toxicol 64:550-557

Hartikainen ES, Lankinen P, Rajasärkkä J, Koponen H, Virta M, Hatakka A, Kähkönen MA (2012) Impact of copper and zinc on the growth of saprotrophic fungi and the production of extracellular enzymes. Boreal Environ Res 17:210-218 
Hartley J, Cairney JWG, Freestone P, Woods C, Meharg AA (1999) The effects of multiple metal contamination on ectomycorrhizal Scots pine (Pinus sylvestris) seedlings. Environ Pollut 106:413-424

Hewitt AE (1998) New Zealand soil classification. Landcare Research Science Series No. 1. Manaaki Whenua Press, Lincoln

Huang Y, Li T, Huang Z-J, Fei Y-H (2008) Ectomycorrhizal fungusinduced changes of $\mathrm{Cu}$ and $\mathrm{Cd}$ speciation in the rhizosphere of Chinese pine seedlings. Pedosphere 18:758-765

Ivanov YV, Savochkin YV, Kuznetsov VV (2011) Scots pine as a model plant for studying the mechanisms of conifers adaptation to heavy metal action: 1. Effects of continuous zinc presence on morphometric and physiological characteristics of developing pine seedlings. Russ J Plant Physiol 58:871-878

Jeyakumar P, Loganathan P, Sivakumaran S, Anderson CWN, McLaren RG (2008) Copper and zinc spiking of biosolids: effect of incubation period on metal fractionation and speciation and microbial activity. Environ Chem 5:347-354

Jeyakumar P, Loganathan P, Sivakumaran S, Anderson CWN, McLaren RG (2010) Bioavailability of copper and zinc to poplar and microorganisms in a biosolids-amended soil. Aust J Soil Res 48:459-469

Kovács B, Prokisch J, Györi Z, Kovács AB, Palencsár AJ (2000) Analytical methods and quality assurance: studies on soil sample preparation for inductively coupled plasma atomic emission spectrometry analysis. Commun Soil Sci Plan 31:1949-1963

Kunito T, Saeki K, Goto S, Hayashi H, Oyaizu H, Matsumoto S (2001) Copper and zinc fractions affecting microorganisms in long-term sludge-amended soils. Bioresour Technol 79:135-146

Liu Q, Loganathan P, Hedley MJ, Grace LJ (2008) Effect of mycorrhizal inoculation on rhizosphere properties, phosphorus uptake and growth of pine seedlings treated with and without a phosphate rock fertilizer. J Plant Nutr 31:137-156

Luo YM, Christie P (1997) Alkaline sewage sludge solids affect the chemical speciation and bioavailability of $\mathrm{Cu}$ and $\mathrm{Zn}$ in the rhizosphere soil solution. Soil Sci Plant Nutr (Tokyo) 43:1041-1046

McBride MB (1991) Processes of heavy and transition metal sorption by soil minerals. In: Bolt GH, De Boodt MF, Hayes MHB, McBride MB (eds) Interactions at the soil colloid-soil solution interface. Kluwer, Dordrecht, pp 149-175

McLaren RG, Clucas LM (2001) Fractionation of copper, nickel, and zinc in metal-spiked sewage sludge. J Environ Qual 30:1968-1975

McLaren RG, Clucas LM, Speir TW, van Schaik AP (2007) Distribution and movement of nutrients and metals in a Pinus radiata forest soil following applications of biosolids. Environ Pollut 147:32-40

McLaren RG, Black A, Clucas LM (2010) Changes in $\mathrm{Cu}, \mathrm{Ni}$, and $\mathrm{Zn}$ availability following simulated conversion of biosolids-amended forest soils back to agricultural use. Aust J Soil Res 48:286-293

Mills T, Arnold B, Sivakumaran S, Northcott G, Vogeler I, Robinson B, Norling C, Leonil D (2006) Phytoremediation and long-term site management of soil contaminated with pentachlorophenol (PCP) and heavy metals. J Environ Manag 79:232-241

Mosquera-Losada MR, López-Díaz ML, Rigueiro-Rodríguez A (2009) Zinc and copper availability in herbage and soil of a Pinus radiata silvopastoral system in Northwest Spain after sewage-sludge and lime application. J Plant Nutr Soil Sci 172:843-850

Mosquera-Losada MR, Ferreiro-Domínguez N, Rigueiro-Rodríguez A (2010) Fertilization in pastoral and Pinus radiata D. Don silvopastoral systems developed in forest and agronomic soils of Northwest Spain. Agric Ecosyst Environ 139:618-628

NZFOA (2009/2010) New Zealand plantation forest industry: facts and figures 2009/2010. New Zealand Forest Owners Association: Wellington

NZWWA (2003) Guidelines for the safe application of biosolids to land in New Zealand and wastes. New Zealand Water Association, Wellington
Pandey AK, Pandey SD, Misra V (2000) Stability constants of metalhumic acid complexes and its role in environmental detoxification. Ecotoxicol Environ Saf 47:195-200

Putoczki TL, Pettolino F, Griffin MDW, Moller R, Gerrard JA, Bacic A, Jackson SL (2007) Characterization of the structure, expression and function of Pinus radiata D Don arabinogalactan-proteins. Planta 226:1131-1142

Reichman SM, Asher CJ, Mulligan DR, Menzies NW (2001) Seedling responses of three Australian tree species to toxic concentrations of zinc in solution culture. Plant Soil 235:151-158

Rigueiro-Rodríguez A, Mosquera-Losada MR, Ferreiro-Domínguez N (2012) Pasture and soil zinc evolution in forest and agriculture soils of Northwest Spain three years after fertilisation with sewage sludge. Agric Ecosyst Environ 150:111-120

SAS Institute Inc (2004) SAS ${ }^{\circledR}$ 9.1.2 users' guide. SAS Institute Inc, Cary, NC

Sevillano-Marco E, Fernandez-Manso A, Castedo-Dorado F (2009) Development and applications of a growth model for Pinus radiata D. Don plantations in El Bierzo (Spain). Inv Agrar Sist Recur Fores 18:64-80

Stevenson FJ (1991) Organic matter-micronutrient reactions in soil. In: Mortvedt JJ (ed) Micronutrients in agriculture. SSSA book series number 4. Soil Science Society of America Inc, Madison, WI, pp $145-186$

Strobel BW, Hansen HCB, Borggaard OK, Andersen MK, RaulundRasmussen K (2001) Composition and reactivity of DOC in forest floor soil solutions in relation to tree species and soil type. Biogeochemistry 56:1-26

Su J, Wang H, Kimberley MO, Beecroft K, Magesan GN, Hu C (2008) Distribution of heavy metals in a sandy forest soil repeatedly amended with biosolids. Aust J Soil Res 46:502-508

Sutton WRJ (1999) The need for planted forests and the example of radiata pine. New Forest 17:95-109

Systat Software Inc (2006) SigmaPlot 10 users' guide: a scientific graphing and data analysis software package. Systat Software Inc., NC

Taylor JP, Wilson B, Mills MS, Burns RG (2002) Comparison of microbial numbers and enzymatic activities in surface soils and subsoils using various techniques. Soil Biol Biochem 34:387-401

Tecator (1983) Application note (AN62/83): determination of the sum of nitrate and nitrite in water by flow injection analysis. Foss North America Technology, Eden Prairie

Tessier A, Campbell PGC, Bisson M (1979) Sequential extraction procedure for the speciation of particulate trace metals. Anal Chem 51:844-851

Toro J, Gessel S (1999) Radiata pine plantations in Chile. New Forest 18:33-44

Van Tichelen KK, Colpaert JV, Vangronsveld J (2001) Ectomycorrhizal protection of Pinus sylvestris against copper toxicity. New Phytol 150:203-213

Wang H, Kimberley MO, Magesan GN, McKinley RB, Lee JR, Lavery JM, Hodgkiss PDF, Payn TW, Wilks PJ, Fisher CR, McConchie DL (2006) Midrotation effects of biosolids application on tree growth and wood properties in a Pinus radiata plantation. Can J Forest Res 36:1921-1930

Wang C, Zhang SH, Wang PF, Hou J, Zhang WJ, Li W, Lin ZP (2009) The effect of excess $\mathrm{Zn}$ on mineral nutrition and antioxidative response in rapeseed seedlings. Chemosphere 75:1468-1476

Wu J, Joergensen RG, Pommerening B, Chaussod R, Brookes PC (1990) Measurement of soil microbial biomass $\mathrm{C}$ by fumigationextraction-an automated procedure. Soil Biol Biochem 22: $1167-1169$

Zhao F-J, Rooney CP, Zhang H, McGrath SP (2006) Comparison of soil solution speciation and diffusive gradients in thin-films measurement as an indicator of copper bioavailability to plants. Environ Toxicol Chem 25:733-742 